\title{
Medical Causes of Death in Preindustrial Europe: Some Historiographical Considerations
}

\author{
JON ARRIZABALAGA
}

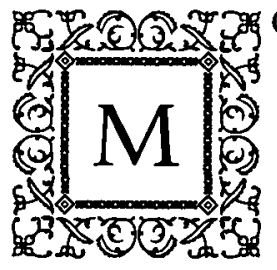

ODERN science and medicine are human constructs. Thus, they constitute a system of thought and representation of reality, not reality itself. Emerging in Europe during the nineteenth century, they promoted a profound transformation in the dominant ways of representating external reality that was exported around the world. The Western framework for understanding scientific and medical reality occupies a central, pivotal position in the modern world and has given enormous influence to those who hold its principles.

Although the perception of the achievements of the last 100 years has led many Westerners to assume that their representations of death and its causes are the most authentic, the "truest," death has always required explanation. Its omnipresent and unavoidable reality is simply too important to humans not to have a system of representing and explaining it. Thus, the philosophical and religious framework of

This study has been partly funded by the research fellowship PB92-0910-Co3-03 of the DGICYT (Spanish Ministry of Education and Science). An earlier Spanish version was published at the Boletín de la Asociación de Demografia Histórica, 11, no. 3 (1993), 25-47. I am indebted to Annie Oakes for her care in revising and improving my English text. I thank Montserrat Cabré, Fernando Salmón, and the participants to the Indiana Conference and the Valencia Workshop (both held in 1993) for their valuable suggestions. I am also thankful to the editors of this volume and an anonymous copyeditor for their careful revision of my article.

This article is dedicated to Patxi Ezkieta (1952-1998). 


\section{Journal of the History of Medicine : Vol. 54, April 1999}

every human society incorporates some representation of death's mystery. ${ }^{1}$

Variations in past and present perceptions of and reactions to death always relate to the social agents who define it, and potential conflicts among these agents influence the social construction of death, in which negotiation among the parties involved often plays a key role. Over the past 100 years or so, university physicians and surgeons in the West have acquired a preponderant role in defining what death is, what a cause of death is, and how death may be explained. But in the past-and still in some contemporary societies - other kinds of "expertise" (priests, healers, and magicians among them) had control over assigning meaning to death or, at least, vied with university practitioners in defining it and its causes.

In this paper I first discuss some general considerations about how death and its causes were understood in preindustrial Europe, with particular emphasis on the fourteenth to early seventeenth centuries. Assuming that, for the purposes of current historical epidemiology and demography, infectious diseases constituted by far the main component of the causes of death, I will later focus on anachronistic fallacies and two critical implications for the history of diseasenamely, the ontological view of diseases and the practice of the retrospective diagnosis of them.

The several individual or collective states (diseases, accidents, injuries, and starvation, among others) that can lead to death are, according to current anthropological thought, a consequence of natural or supernatural causes, or the effect of human malevolence. ${ }^{2}$ In this paper I have restricted my view to a small part of the complexities of the social phenomenon of death by focusing on the natural causes which are the subject of medical knowledge. I deal with the causes of death in late medieval and early modern Europe as understood by contemporary medical authorities of those periods, on the assumption that the word "cause" does not have the same meaning in every

1. For general overviews on this topic, see Philip P. Wiener, ed., Dictionary of the History of Ideas (New York: Charles Scribner's Sons, 1973), I, 634-46; W.T. Reich, ed., Encyclopedia of Bioethics (New York: The Free Press, 1978), I, 221-307. On Western perceptions and reaction to death, see Philippe Ariès, Westem Attitudes Touvards Death: From the Middle Ages to the Present (Baltimore, Md.: Johns Hopkins University Press, 1974); Michel Vovelle, La mort et l'Occident de 1300 à nos jours (Paris: Gallimard, 1983).

2. David Landy, "Anthropological perspective of death," in Reich, (n. I) Encyclopedia of Bioethics I, 22I-29. 
historical or cultural context. I address three main issues: (I) the process of medicalization of death and its causes; (2) the relationship between the causes of death and nosological systems; and (3) the peculiar status of the diagnosis of the causes of death in early modern medical practice.

\section{MEDICINE AND DEATH IN PREINDUSTRIAL EUROPE}

Since the thirteenth century, death has undergone a gradual medicalization at the hands of "scholastic medicine." That is, physicians acquired a greater role in attendance at deaths, as well as explaining how and why death occurred. ${ }^{3}$ Physicians applied a learned kind of medicine that resulted from the assimilation of Aristotelian philosophy (of course, adequately Christianized) and of a great number of works by the ancient medical authorities (mainly Hippocrates and Galen) that had been translated from Greek and Arabic, works often synthesized, summarized, or commented on by Byzantine and Arab physicians. Scholastic (or academic) medicine originated in southern Europe between the early twelfth and the early thirteenth centuries and quickly developed in the university medical schools, which had spread all over Western Europe since the first part of the thirteenth century. As a result, a new kind of medical practitioner appeared, possessing substantial theoretical knowledge. He was also dedicated to a lucrative professional practice which was gradually legitimized, not only by the possession of particular skills and techniques, but also by the political support of civil and ecclesiastical authorities. ${ }^{4}$

During the late sixteenth century, the scholastic method of medical education and practice was replaced by others, most of which were university-based. But well into the nineteenth century, universityeducated practitioners continued to serve only part (albeit an increasingly important segment) of the population's demands. They did so in

3. By no means do I deny that to some extent death had been already medicalized in Western medieval Europe before the thirteenth century; I merely want to emphasize that the construction of "scholastic medicine" pointed to a major landmark in this respect.

4. On this topic, see the recent overviews by Nancy G. Siraisi, Medieval and Early Renaissance Medicine. An Introduction to Knowledge and Practice (Chicago: University of Chicago Press, 1990); Danielle Jacquart and Françoise Micheau, La médecine arabe et l'occident médiéval (Paris: Maisonneuve and Larose, I 990); Michael R. McVaugh and Nancy G. Siraisi, eds., Renaissance Medical Leaming. Evolution of a Tradition, Osinis, 2nd series, 1990, 6; Luis GarcíaBallester, Roger K. French, Jon Arrizabalaga and Andrew Cunningham, eds., Practical Medicine from Salemo to the Black Death (Cambridge: Cambridge University Press, 1994). 


\section{Journal of the History of Medicine : Vol. 54, April 1999}

competition with other practitioners of both sexes and other religious faiths who had been trained in an open system and lacked university education. ${ }^{5}$

Thus, during the 600 years between the thirteenth and the nineteenth centuries, a historical perspective shows that death and its causes continued to be perceived in a pluralistic way. Meanings or causes of death were often a matter of conflicting views and disputes encountered among numerous social agents inside and outside the medical world. Only since the second half of the nineteenth century has a single medical view of death become dominant in the West, a result of the diffusion of modern medicine, a medicine based on the principles and methods of natural science which Western physicians assumed as the single theoretical framework behind their practices.

Beginning as early as the fourteenth century, moral, religious, and even fictional works dedicated to the topic of death proliferated throughout Western Europe, becoming popular literary genres such as the "Art of Dying" (Ars moriendi) or the scenic poem, "Dance of Death." 6 The earliest specifically medical works focusing on death appeared in the mid-seventeenth century. ${ }^{7}$ The discipline of thanatology, that is, the scientific study of death, its causes, and phenomena, developed as a part of forensic medicine during the nineteenth century. ${ }^{8}$ During the eighteenth century, the number of medical works dealing with death and/or any of its varieties (e.g., sudden death, apparent death, and violent death) steadily increased. ${ }^{9}$ But before

5. On the "open model" of medical teaching and its contrasts with the "closed" or institutionalized one, see Luis García-Ballester, La medicina a la València medieval (València: Edicions Alfons el Magnànim, 1988), pp. 42-45.

6. On the genre of the Ars moriendi, see Mary Catherine O'Connor, The Art of Dying Well: The Development of the Ars moriendi (New York: Columbia University Press, I 942; fac. repr.: New York, AMS Press, 1966). On the representations of the physician in the literary tradition of the "Dance of Death," see Aldred Scott Warthin, "The Physician of the Dance of Death," Amm. Med. Hist., new series, 1930, 2, pp. 35I-71, 453-69, 697-710; and 1931,3 , pp. 75-109, 134-65.

7. Among the earliest are those resulting from two university disputations that were apparently held at Wittenberg and Jena in the I6sos. See P.P. Roberus, $\Theta A N A T O \Lambda O \Gamma L A$, sive disputatio philosophica de mone (Wittenberg, 1656); Caspar Posner, Disputatio Physica de Morte (Jena: Prelo Nisiano, 1659) [Theodorus Rollius, respondent].

8. One of the foundational works of this discipline might be $S$. Anschel, Thanatologia, sive in mortis naturam, causas, genera ac species et diagnosis disquisitiones (Gottingen, 1795). In English, it seems to have appeared for the first time in Dunglison's Medical Lexicon of 1842 (see Oxford English Dictionary, compact edition, p. 3276). Since the mid-twentieth century, thanatology deals with death and dying from a more global viewpoint, being particularly concerned with their psychosocial aspects.

9. For a historical overview of the medical literature on death, see the bibliographical information reported by the various series of the Index Catalogue under the "Death" entry 
then, as Erwin Ackerknecht stressed more than thirty years ago, European university physicians "were busy enough fighting, alleviating or diagnosing death."10

Indeed, medical works properly dealing with death could hardly be found before 1650, except for some brief pseudo-Hippocratic practical works on the signs of death that were widely circulated in preindustrial Europe. These works, often known under the common designation "ivory capsule" (Capsula eburnea) and mostly spurious, probably derived from the authentic Hippocratic Prognosis. They all dealt with signs of life and death so that physicians could identify them in their patients and, therefore, foretell their death. ${ }^{11}$ Practitioners' concern with forecasting death was not only related to the fact that every failure in predicting it could cause professional discredit, but also had wider implications because a patient who met with an unanticipated death and had not received the last rites risked eternal damnation in a society dominated by the Roman Catholic Church.

But leaving aside the "ivory capsule" tradition, does this almost entire absence of specific medical works on death prior to I650 mean that university practitioners had failed to conceptualize it? Such a case seems unlikely given the program of "rational medicine" that scholastic practitioners developed. While there were no systematic treatments of the topic, passages referring to death, its kinds, causes, and/or signs appeared in works of Greek, Roman, and Arab medical authorities which were widely used and commented on by medical practitioners from the thirteenth century onward. Among them there are the Hippocratic Prognosis, in which the "Hippocratic face" (facies Hippocratica) is described, Galen's De marcore, De temperamentis and other works, Rhazes's Ad regem Mansorem, Avicenna's Canon, and Celsus's De Medicina. ${ }^{12}$

Death was also an incidental topic in plague treatises and other

Io. Erwin H. Ackerknecht, "Death in the history of medicine," Bull. Hist. Med., I968, $42,19-23$.

II. Among these works are Analogium, Liber praestantiae, Liber de veritate, Prognostica, De pustulis, Secreta, and Signa vitae et mortis. During the Middle Ages these works circulated under two different translations, an anonymously translated Greek-Latin version of the fifth or sixth century, and an Arabic-Latin one by Gerard of Cremona (twelfth century). See Pearl Kibre, Hippocrates Latinus. Repertorium of Hippocratic wnitings in the Latin Middle Ages, revised ed. (New York: Fordham University Press, 1985), pp. I Io-23, 226-27.

12. Hippocrates, Liber prognosticonum (London: Loeb, 1923), pp. 8-I I [book 2, ch. 2]. Galen, De Marcore, in Opera omnia, ed. Kühn, VII, 674-75; De temperamentis, lib. I, cap. III; lib. II, cap. II (ibid., I, 522-23, 582). For other passages where Galen also dealt with death, see Opera omnia, XX, 405. Rhazes, Ad regem Mansorem libri X, book X, ch. 2I (Basel: $H$. Petrus, I 544), pp. 306-9. See the following passages of Avicenna's Canon: 1/1, doct. 4, ch. 


\section{Journal of the History of Medicine : Vol. 54, April 1999}

specialized works written by late medieval and Renaissance university practitioners. This is the case, for instance, of the Catalan doctor Jacme d'Agramont who wrote Regiment de preservació de pestilencia (Regimen for preservation from the plague), in Lérida (Catalonia) at the beginning of the plague in 1348. Agramont considered that "the likelihood of death frequently carried with it the necessity to determine whether in doubtful cases it had indeed occurred." In mentioning apoplexia, which he identified with brain apostema, as the effect of overcooling by a pestilential air, he wrote that it brought about a "sudden loss of movement and of feeling which renders men so inert that one can hardly know, either by the pulse or by the breath, whether they are dead or living." For this purpose Agramont suggested two simple proofs that he described in detail because of his desire to serve the common good. The first consisted of observing whether a very thin shred of wood, held near the nostrils or the mouth of someone supposedly deceased, moves as a result of the air passing in and out with the breath. The second consisted of seeing whether water in a glass put on the chest near the heart moves as a result of the heartbeat. Agramont insisted that this question was not at all trivial, for "it is certain that many men and women who suffer from the disease [apoplexia] are thought to be dead by the common people and many are buried alive." Therefore, it was advisable that "all those who are subject suddenly to such accident [i.e., sudden death] be carefully watched and examined by physicians before they are buried." Failing this, Agramont recommended that, in accord with Avicenna's counsel, a period of seventy-two hours be allowed to elapse before the burial of the deceased. ${ }^{13}$

As well as this interest in signs confirming death, there are at least two other kinds of sources in which late medieval and early modern university practitioners reflected their views of death. The first was a series of treatises on how to prolong life and delay old age and death. Physicians and natural philosophers such as Roger Bacon, Petrus Hispanus, Pietro d'Abano, Arnau de Vilanova, Bernard de Gordon, Gabriele de Zerbi, Marsiglio Ficino, Luigi Cornaro, and

\footnotetext{
$3 ; \mathrm{I} / 3$, ch. I; III/9, tract. I, ch. 9 ; III/11, trac. 2, ch. 6-7; IV/2, tract. I, ch. 92, 94, 97-99. Celsus, De medicina, II.6 (London: Loeb, 1960) II, 108-17. Celsus's work remained lost until its rediscovery during the fifteenth century.

13. Jon Arrizabalaga, "Facing the Black Death: perceptions and reactions of university medical practitioners," in García-Ballester et al., (n. 4) Practical Medicine, pp. 237-88.
} 
others wrote according to the tradition established by Aristotle's $O n$ Length and Shortness of Life and On Youth and Old Age: On Life and on Death. ${ }^{14}$ Indeed, their works sometimes were commentaries or mere paraphrases of Aristotle's.

A second, different sort of interest was represented by medical works referring to legal issues, which appeared in the late sixteenth and early seventeenth centuries. Among the earliest are the Declarations to be made by surgeons about those many diseases and kinds of death which happen (I 586 ), published in Spanish by the Castilian royal physician and surgeon of Philip II, Juan Fragoso (ca. I 530-I 597), and reprinted many times in both Spanish and Italian during the sixteenth and seventeenth centuries. There were also the Four books of practitioners' reports, where all those things which they usually refer to in forensic and public causes are dealt with at large, written in Latin by the Sicilian doctor Fortunato Fedele (1550-I630) and reprinted no fewer than three times during the seventeenth century. ${ }^{15}$

Although a number of relevant differences can be detected in the contents of various works, all those written from the time of Galen to the middle of the sixteenth century referred to the well-known lamp metaphor to explain life and death. According to this metaphor, "radical" or "innate moisture" feeds the "innate heat" of which life consists, like the lamp oil feeds the flame. As the radical moisture dries up, the innate heat decreases, and, thus, the body gradually becomes cold and dry. Natural death arrives when the innate heat is extinguished as a result of the lack of radical moisture, but death can also happen because of the latter's putrefaction or rapid dissipation. From the moment of conception, every individual receives a qualitatively and quantitatively variable portion of radical moisture. Depending on its amount and quality and the adequacy of its combustion, life will be shorter or longer, so that natural death will happen sooner or later. Achieving an optimal use of this radical moisture and

14. Aristotle, Parva naturalia, trans. W.S. Hett (London: Loeb, 1957), pp. 394-409, 4 1 2-27. On this question and the works of some of these physicians and natural philosophers, see Sheila R. Johansson, "Longevity theory: optimism, pessimism and the causes of death", presented at the History of Registration of the Causes of Death conference, Bloomington, Indiana, I I-I 4 November 1993.

I5. Juan Fragoso, "Declaraciones que han de hacer los cirujanos acerca de muchas enfermedades y muchas maneras de muertes que suceden," in Fragoso, Chinurgia universal (Madrid: Vda. de Alonso Gómez, i 586); Fortunato Fedele, De relationibus medicorum libri quatuor. In quibus ea omnia quae forensibus ac publicis causis medici referre solent, plenissime traduntur (Palermo: J.A. de Franciscis, 1602). 
preserving it from interior and exterior injuries by following an appropriate lifestyle formed the basis of the aforementioned treatises on how to prolong life. ${ }^{16}$

In sum, the cause-of-death issue did not become a genuinely medical one until the nineteenth century. Earlier university medical practitioners were much more interested in discussing causes of illness than in assigning causes of death.

\section{Causes of Death and the Nosological Systems}

If only those causes of death which are today acceptable within scientific medical discourse are taken into consideration, a second general question arises concerning the medical framework in which diseases and their causes are conceptualized. During the nineteenth century most diseases that present-day Western medicine identifies as such, "crystallized in the form of specific entities."17 Gradually a causal system whose origins went back to classical Greece had been replaced by a Newtonian-Laplacian one, and the change played a key role in this modernizing process. ${ }^{18}$ Here I focus on the case of the infectious diseases, doubtless the disease group that has until recently caused the highest percentage of deaths in most societies.

Using the case of plague, Andrew Cunningham has shown how different present-day criteria for defining infectious diseases are from those applied in prelaboratory times - that is, before the second half

16. For an overview of the ideas about the prolongation of life inside and outside this tradition, see Gerald J. Gruman, $A$ History of the Ideas about the Prolongation of Life. The Evolution of Prolongevity Hypotheses to 1800 , Transactions of the American Philosophical Society, new series, vol. LVI, part 9 (Philadelphia: American Philosophical Society, 1966). For particular topics, see Thomas S. Hall, "Life, death and the radical moisture. A study of thematic pattern in medieval medical theory," Clio Med., 1971 , 6, 3-23; Peter H. Niebyl, "Old age, fever, and the lamp metaphor," J. Hist. Med., 197I, 26, 351-68; Michael R. McVaugh, "The humidum radicale in thirteenth-century medicine," Traditio, I974, 30, 259-83.

17. Charles E. Rosenberg, "Disease in history: frame and framers," in Rosenberg and Janet Golden, eds., "Framing disease: the creation and negotiation of explanatory schemes," Milkbank Q., 1989, 67, supplement $1,1-16$.

18. See Anne Fagot-Largeault, "On medicine's scientificity: Did medicine's accession to scientific positivity in the course of the mid-nineteenth century require giving up some causal (etiological) explanation?" in Corina Delkeskamp-Hayes and Mary Ann Gardell Outter, eds., Science, Technology, and the Art of Medicine: European-American Dialogues (Dordrecht: Kluwer Academic Publishers, 1993), pp. 199-226. For a nineteenth-century case illustrating the reluctance with which the old causal system was displaced, see Christopher Hamlin, "Predisposing causes and public health in early nineteenth-century medical thought," Soc. Hist. Med., 1 992, 5, 43-70. 
of the nineteenth century. ${ }^{19}$ According to laboratory medicine and the germ theory, the laboratory detection of the specific microbial cause of plague (Yersinia pestis) in the tissues of the ill person is now the key factor for the diagnosis of plague. All the remaining aspects (signs and symptoms, clinical varieties, epidemiology, pathology) are subordinate to it. In contrast, prelaboratory university physicians identified plague through its symptoms and development and shared a view of causality radically different from the present one. Before the laboratory it was accepted that patients suffered from "mixed" diseases, and that the "morbid matter" freely moved within the body, which implied that any disease could change its seat, and even be transformed into another one. The prelaboratory causal system was based on the supposed existence of a hierarchical causal chain where the macrocosm and microcosm were closely related to each other. This causal chain extended from the "first cause" to the "immediate cause" through a long series of intermediate causes. One single cause could lead to different diseases; one single disease could have multiple etiologies. ${ }^{20}$

As Cunningham states, when one claims that disease $X$ in the past and disease $Y$ in the present are identical, one is obliged to define the conditions to be satisfied in order to affirm this claim of sameness, of identity. "And this is a philosophical and historiographical question, not a technical medical one." 21 Because there is an essential discontinuity between the identity of plague - or of any other infectious disease-before and after the laboratory and an incommensurability between the causal understandings of both plagues, "we are simply unable to say whether they were the same, since the criteria of 'sameness' have been changed." 22 Later I will focus upon the implications of this argument for the history of disease. Now, I would like merely to emphasize that an overlap of two or more medical systems in any given society could induce historical demographers and epide-

19. Andrew Cunningham, "Transforming plague: the laboratory and the identity of infectious disease," in Andrew Cunningham and Perry Williams, eds., The Laboratory Revolution in Medicine (Cambridge: Cambridge University Press, 1992), pp. 209-44.

20. Ibid.; Lester S. King, Medical Thinking. A Historical Preface (Princeton, N.J.: Princeton University Press, 1982), pp. I87-223; Codell Carter, "Causes of disease and causes of death," Continuity and Change, 1997, 12, I 89-98. On the earliest medical conceptualizations of plague in pre-laboratory Europe, see, for example, Arrizabalaga, (n. 13).

21. Cunningham, (n. 19), p. 2 I0.

22. Ibid., p. 242 . 
miologists to underestimate its death rates and to bias its pattern of causes of death. ${ }^{23}$

\section{The Diagnosis of the Causes of Death}

A third general question about diseases as causes of death derives from the nature of the records (usually the registers of death) created for this purpose and concerns the particular position of diagnosis in medical practice. In most developed European countries registration of deaths and causes of death were neither systematically made by university-trained practitioners, nor made according to a learned medical language (either Latin or vernacular) until the last decades of the nineteenth century. ${ }^{24}$ But even when educated practitioners were involved, nosology and diagnosis represented two different levelsof medical thought. Any specified cause of death reflects the result of a negotiation among a number of social agents who can be, and usually are, involved in defining death and its causes, rather than a direct expression of any contemporary medical nosology.

A register of the causes of death could have been written for many possible, and not necessarily medical, purposes. Landry and Lessard's examination of parish registers in early modern Quebec shows that "most of the causes of death noted in burial certificates served in fact to justify the priest for having been incapable of giving the last sacraments," dispelling any suspicion of negligence upon his part in cases like sudden death, frequent vomiting, mental sickness or unconciousness, and violent death. ${ }^{25}$ On the other hand, registers collected expressly for the purpose of recording causes of death often do not provide a better reflection of deaths by cause. The concealment which those responsible for public health have often shown throughout history in the face of a serious epidemic disease (plague, smallpox, cholera, typhus, yellow fever) is an example. Before a pestilence was

23. See Ann Jannetta, "Problems of classifying deaths in nineteenth-century Japan" in this issue, for a relevant example.

24. See in this issue Hans Christian Johansen, "The development of reporting systems for causes of death in Denmark"; John Rogers, "Reporting causes of death in Sweden, I750-1950"; Michael Stolberg, "National statistics on the causes of death in nineteenthcentury Bavaria"; and see Frans van Poppel and Jitse P. van Dijk, "The development of cause-of-death registration in Netherlands, 1865-1955," Continuity and Change, 1997, 12, $265-87$.

25. Yves Landry and Renald Lessard, "Causes of death in seventeenth- and eighteenthcentury Québec," Hist. Methods, 1995, 29, no. 2, 49-\$7. 
declared, officials sanctioned under- or inaccurate reporting because of the panic this information provoked in the communities involved and the subsequent damage of every kind that it caused. Thirty years ago, Bartolomé Bennassar expressively referred to this attitude as la peur $d u$ mot. ${ }^{26}$ That this attitude by no means was limited to the past is plainly shown by a recent incident concerning AIDS. In the midI980s, facing the sharp criticisms that U.S. blood bank authorities received for not having given the warning notice from the first moment that they suspected post-transfusion AIDS, the head of the New York Blood Center replied: "You shouldn't yell fire in a crowded theater, even if there is a fire, because the resulting panic can cause more deaths than the threat."27

The case of AIDS also illustrates that sometimes the actual cause of death can be deliberately hidden to avoid social stigmatization of the deceased and/or of surviving friends and family. Giulia Calvi has recently provided us with a number of seventeenth-century examples of this behavior. During the Florentine plague of $1630-1633$, people sometimes managed to obtain from barber-surgeons or doctors falsified death certificates, attributing the cause of death of relatives who had been victims of plague to some other cause in order to ensure an honorable death to their loved ones and to avoid the social dishonor of mass burials outside the church or other consecrated ground. ${ }^{28}$

Sometimes the reasons for hidden mortality attributable to a particular disease are multiple. Linda Bryder has illustrated this point with nineteenth- and twentieth-century tuberculosis. Bryder has shown that this disease might be missing from the registers because of failure to diagnose it (medical techniques did not completely guarantee its diagnosis until after the World War II) as well as because of the reluctance of the victim's relatives to admit its presence. A diagnosis

26. Bartolomé Bennassar, Récherches sur les grandes épidémies dans le nord de l'Espagne à la fin du XVle siècle. Problèmes de documentation et de méthode (Paris: S.E.V.P.E.N., 1969), pp. $56-57$.

27. Quoted in Mirko D. Grmek, History of AIDS: Emergence and Origin of a Modem Pandemic, trans. Russell C. Maulitz and Jacalyn Duffin (Princeton, N.J.: Princeton University Press, 1990), p. 162.

28. Guilia Calvi, Histories of a Plague Year: The Social and the Imaginary in Baroque Florence, trans. Dario Biocca and Bryant T. Ragan, Jr. (Berkeley: University of California Press, I989), pp. 104-17. 
of tuberculosis could cause difficulty for the heirs in receiving life insurance and/or lead to their social stigmatization. ${ }^{29}$

There are even more mystifying reasons for deliberately concealing causes of death that may apply to the past as well as the present. Lindsay Prior and Mick Bloor have analyzed three scientific representations of death and its causes in contemporary Western societies: the life table, the mortality report, and the death certificate. Present-day practitioners are primarily concerned with allocating a death to "an approved conceptual and explanatory framework, rather than with providing detailed empirical findings." They are interested, first and foremost, "in providing 'good organizational reasons' for dying (in the required format)." Thus, to modern certifiers, "death is purely a bodily affair to be explained according to the geography of human anatomy and the principles of forensic pathology. In this respect the entire notion of a 'natural' death serves both to obscure and to naturalize the effects of the social and economic inequalities which are related to mortality differentials in the advanced industrial world." 30

\section{ANACHRONISM IN THE HISTORIOGRAPHY OF DISEASE}

From the preceding discussion, it is difficult to imagine that any medical expression of cause of death can be fully understood outside of its relevant representational (or historical) framework. As we study diagnosis "etiquette" from the representational framework of modern medicine, the farther back we go into the past, the greater our difficulties.

Obviously, these difficulties are qualitatively greater if we deal with prelaboratory medicine - that is, medicine before the nineteenth century. ${ }^{31}$ However, even with late twentieth-century modern medicine, we are not entirely free from troubles. For instance, the conceptual framework of present-day medicine is increasingly challenged by

29. Linda Bryder, "'Not always one and the same thing': the registration of tuberculosis deaths in Britain, I900-1950," Soc. Hist. Med., 1996, 9, 253-65. A reluctance to admit the real cause of death for similar reasons is also referred by Van Poppel and Van Dijk, (n. 24).

30. Lindsay Prior and Mick Bloor, "Why people die: social representations of death and its causes," Science as Culture, I 991 , 3, 346-74, pp. 368-70. See also Jannetta, (n. 23); Stolberg, (n. 24).

31. On these difficulties, see the review by Josep Bernabeu-Mestre, "Enfermedad y población: Una aproximación crítica a la epidemiologia històrica española," Rev. Salud Pública, I991, 2, 67-88, especially pp. 73-74. 
new diseases. Again, the case of AIDS illustrates the point. Unlike most diseases, AIDS is an entirely new phenomenon, which first occurred at the end of the twentieth century. This may be attributed not only to the specific ecological and social conditions that have made the outbreak of AIDS possible, but also to Western medicine's new technological tools. As Mirko Grmek has stated, a pandemic like AIDS did not seem so feasible "before the mingling of peoples, the liberalization of sexual and social mores, and, above all, before progress in modern medicine had accomplished the control of the majority of serious infectious diseases and introduced intravenous injections and blood transfusion." 32

But there is yet another reason AIDS should be considered as a disease peculiar to the late twentieth century: it is also new because "its pathological manifestations could not even have been understood as a disease before the advent of new concepts resulting from recent developments in the life sciences." 33 I do not need to insist on the conceptual distance between the "morbid species" pattern of infectious disease that Western modern medicine shaped during the late nineteenth and the early twentieth centuries (signs and symptoms of lesions and dysfunction coupled to a specific cause) and the new pattern represented by AIDS (an infectious disease caused by a retrovirus), which can have as potential signs a numerous, and continuously growing, group of specific morbid species mainly consisting of opportunistic infections and unusual cancers. ${ }^{34}$

But putting aside the case of AIDS, I would like now to deal with the historical practice of anachronism and two of its most serious implications for the history of disease - namely, the practices of nosological ontologism and retrospective diagnosis. To a greater or lesser extent, these practices involve current historical epidemiology and demography because for the purposes of these disciplines disease is by far the main cause of death in most human societies.

32. Grmek, (n. 27) History of AIDS, p. 109. According to the concept of pathocènose

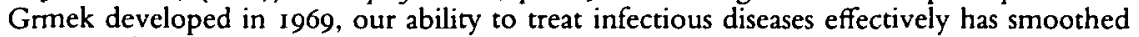
the way for the emergence of AIDS and other new infectious diseases. See Mirko D. Grmek, "Préliminaires d'une étude historique des maladies," Ann. E.S.C., 1969, 24, 1437-83.

33. Grmek, (n. 27) History of AIDS, p. 109

34. Nowadays, according to the Centers for Disease Control in Atlanta (1993), an individual is considered to have AIDS if, in addition to seropositivity, he or she suffers from one or several of the twenty-eight specific diseases associated with AIDS. 
254 Journal of the History of Medicine : Vol. 54, April 1999

\section{Anachronism as a Historical Practice}

More than sixty years ago, in dealing with the problem of historiographical anachronism, the English historian Herbert Butterfield characterized as "whig history" the tendency then current among many historians of England to write in favor of the Protestants and the Whig party, to praise the successful revolutions, to emphasize certain principles of progress in the past, and to produce a history that represented the legitimation, if not the glory, of the present. ${ }^{35}$ As Adrian Wilson and T.G. Ashplant have claimed, whig history is but one specific variety of the general problem of present-centeredness, that is to say, "the position of the historian within the perceptual and conceptual categories of the present constrains and tends to distort his/her construal of the past." This problem is "inherent in the process of historical research," making every historical inference problematical. But awareness of this "helps to rule out certain kinds of anachronistic fallacy." 36

In recent decades, coinciding with increasing and multifaceted challenges to scientific world view, there has been an important reaction against whig history and other anachronistic fallacies in the history of medicine and the history of science. For some time both of these disciplines were favorable breeding grounds for anachronism because, among other reasons, the idea of progress held great prestige among physicians and scientists - two social collectives whose professional closeness to historians of medicine and science has usually made it difficult for the historians to remain outside of the influence of physicians and scientists. One of the most obvious results of historiographical anachronism has been the progressive devaluation of history as we go farther back in time or away from the Western developed world. This, for instance, helps to explain the decline of interest in medicine and natural philosophy by Western historians before the eighteenth century. It is also a key to understanding why Western historians still pay such scant attention to the history of medicine and science in developing countries.

Anachronistic approaches to the history of human diseases still

35. H. Butterfield, The Whig Interpretation of History (1931; Harmondsworth: Penguin, 1973).

36. Adrian Wilson and T.G. Ashplant, "Whig history and present-centred history," Hist. $J ., 1988,31, \mathrm{I}-16$, p. 16; Ashplant and Wilson, "Present-centred history and the problem of historical knowledge," Hist. J., 1988, 31, 253-74, p. 274. 
enjoy a wide audience among historians of medicine. This has meant that infectious disease before germ theory is still too often studied from the viewpoint of laboratory medicine. And this perspective, unless we are concerned with the biological and ecological history of disease, is not the most suitable to study past human diseases because it severly restricts the scope of historical research. Indeed, behind the blinders of modern medicine, the study of any past disease is limited unless it anticipates further medical nosography and nosology within a linear and progressive conception of the historical evolution of modern medicine. Or it may be presented as a naive or picturesque counterpoint to scientifically based, supposedly definitive medical knowledge.

\section{Nosology and Ontologism}

During the last two decades, relations between biology and culture in the field of human diseases have given rise to bitter academic controversies in the Western world. I do not intend to deny the biological reality inherent in most human diseases. Nevertheless, I emphasize that a real understanding of disease always goes far beyond its mere biology. As Charles Rosenberg has pointed out, "there is no simple and necessary relationship between disease in its biological and social dimensions," so that "meaning is not necessary, but negotiated." 37

Conceptions of infectious diseases and the diagnostic terms for medical causes of death can be allocated along a wide intellectual spectrum, the extremes of which are occupied by the most radical expressions of philosophical realism and relativism. ${ }^{38}$ The idea that such diseases are "natural kinds" and therefore exist like animal, vegetable, and microbial species, is placed at the realist extreme of this spectrum. Yet, this conception has enjoyed a notable persistence in the historiography of infectious disease.

Ontologism, which in the medical past often sprang up under different formulations, received new encouragement in the late nineteenth and early twentieth centuries with the development of the

37. Charles Rosenberg, "Disease and social order in America: perceptions and expectations," in Elisabeth Fee and Daniel Fox, eds., AIDS: The Burdens of History (Berkeley, University of California Press, 1988), pp. 12-32, p. 12.

38. On the philosophical question of the nature of disease, see, for instance, Lawrie Reznek, The Nature of Disease (London: RKP, 1987). 
germ theory for infectious diseases, a theory that specifically related each morbid species to its causal germ..$^{39}$ As a result of bacteriologists' need to legitimize their theory in the face of their numerous opponents and of the primacy they eventually achieved in modern medicine, during the late nineteenth and early twentieth centuries the history of infectious diseases was rewritten. ${ }^{40}$ Cunningham shows that bacteriologists argued that the germ theory had provided modern medicine with "the first successful understanding of plague and other terrible diseases, which replaced the old, unsuccessful and misguided attempts" in order to achieve this aim. ${ }^{41}$

According to this "bacteriologic view," the history of medicine was "presented as the story of the fight of evidence and common sense over theory and stupidity," a battle eventually won in the laboratory. Thus, they invented their own genealogy vindicating men such as Fracastoro, Leeuwenhoek, Redi, Spallanzani, and Semmelweis as microbiologists and bacteriologists avant-la-lettre. And they introduced themselves as "the successors to these far-sighted men whose fate had inevitably been not to have been appreciated in their own day." 42 The theoretical developments in medical nosology since the r920s have notoriously tempered the ontologist "excesses" initially produced by germ theory and, consequently, this approach to human disease has been abandoned gradually by most medical historians, although it has not yet entirely disappeared. ${ }^{43}$

\section{Retrospective Diagnosis}

The primacy of modern medicine and science in our society has meant that the representation of disease in these fields has been legitimized to the extent that for many medical historians, identifying past human diseases in terms of present-day nosology is always possible,

39. On ontologism in the history of medicine, see Owsei Temkin, "The scientific approach to disease: specific entity and individual sickness," in O. Temkin, The Double Face of Janus and Other Essays in the History of Medicine (Baltimore, Md.: The Johns Hopkins University Press, 1987), pp. 441-5s.

40. On this topic, see Lloyd G. Stevenson, "Science down the drain: on the hostility of certain sanitarians to animal experimentation, bacteriology and immunology," Bull. Hist. Med, I955, 29, I-26.

4I. Cunningham, (n. I9), p. 240 (emphasis in original).

42. Ibid., 238-42, p. 240 .

43. On the theoretical developments of nosology during the twentieth century, see Pedro Lain Entralgo, El diagnóstico médico: Historia y teoría (Barcelona: Salvat, 1982), pp. II9-82. 
provided that adequate documentary and/or material sources for this purpose are available. ${ }^{44}$ Although during recent decades there has been increasing caution toward retrospective diagnosis, its practice continues to have a notable impact on the historiography of disease, and there are still many researchers who, consciously or unconsciously, continue to include it as a usual part of their discourse. ${ }^{45}$ Furthermore, there are some fields of study where retrospective diagnosis has become an objective in itself. This is the case of the historical pathobiographies, an area of study which, as a result of its usually spectacular conclusions, often enjoys a disproportionately high social visibility, in spite of its usually low research standards. ${ }^{46}$

But can we be sure that the plague (pestis) of the preindustrial societies identifies itself with the disease now known as such? How do we know if the disease termed a "leprosy" (lepra) in a medieval document is the same as what we now call leprosy? Was the French disease morbus gallicus of late fifteenth-and sixteenth-century medical and lay documents, which Girolamo Fracastoro baptized as syphilis in 1530 , or the lues venerea of the seventeenth and eighteenth centuries the same morbid entity as the present venereal syphilis? Where should the great chapter of "fevers" of prelaboratory medicine be located in present-day nosology? Can we make any sense of the mal di petto? What was "teething" about?

I have already referred to the wide chasm between prelaboratory and laboratory medicine and to the essential discontinuity between the identity of disease as conceptualized by Western medicine before and after the laboratory. However, as Cunningham remarked in the case of infectious diseases, "historians and bacteriologists regularly put themselves through intellectual contortions in their determination

44. This attitude is clearly illustrated by Mirko D. Grmek, Les maladies à l'aube de la civilisation occidentale: Recherches sur la réalité pathologique dans le monde grec préhistorique, archaique et classique (Paris: Payot, 1983).

45. For a plain example of this approach, see Carlo M. Cipolla, I pidocchi e il Gran Duca (Bologna: Il Mulino, I979); Cipolla, Miasmi ed umori (Bologna: Il Mulino, 1989).

46. As a recent controversial example, which found resonance even in the newspapers, see Margaret Davies and Trevor A. Lloyd Davies, "Resurrection or resuscitation?" J.R. Coll. Physicians Lond., I991, 25, no. 2, 167-70. In this surprising article about the historical question of Christ's death and resurrection, the authors conclude from a reading of the Bible in the light of present-day medical knowledge, that Christ did not die and, therefore, was not resurrected. Instead, he was resuscitated; that is, he merely recovered from a heart collapse. 


\section{Journal of the History of Medicine : Vol. 54, April 1999}

to make identifications across this divide, and presumably will continue to do so, bizarre as their assertions sometimes are by their own usual standards of evidence and proof." 47

Even beyond these considerations, we might wonder to what extent retrospective diagnosis provides historico-medical research with relevant knowledge about how and why a specific society perceived and reacted to the attack of "social diseases." As Collingwood stated, using the battle of Trafalgar as an example of naval history,

Unless you can see the battle through the eyes of a man brought up in sailing-ships armed with broadsides of short-range muzzle-loading guns, you are not even a beginner in naval history, you are right outside it. If you allow yourself to think for a moment about the tactics of Trafalgar as if the ships were driven by steam and armed with long-range breech-loading guns, you have for that moment allowed yourself to drift outside the region of history altogether. ${ }^{48}$

\section{FINAL COMMENTS}

In the context of an interdisciplinary venture among historical demographers, epidemiologists, and medical historians, there is no avoiding the fact that the practice of retrospective diagnosis-at least grosso modo - is indispensable, from a methodological viewpoint, to the study of the biological and ecological history of humankind and of its diseases. Therefore, retrospective diagnosis plays an important role in research fields like paleopathology, historical epidemiology, and historical demography. Nor can I ignore its valuable role in the construction of larger biohistorical models based to a great extent on the results of those disciplines. Let us remember, for instance, the wide-ranging studies by Alfred Crosby and William McNeill on the history of the world or global history, or those by Kenneth Kiple on the biological history of African-American populations. ${ }^{49}$

All these historical constructions and others focused on the biologi-

47. Cunningham, (n. I9), p. 242. 58.

48. R.G. Collingwood, An Autobiography (Oxford: Oxford University Press, 1978), p.

49. Alfred W. Crosby, The Columbian Exchange: Biological and Cultural Consequences of 1492 (Westport: Greenwood, 1972); Crosby, Ecological Imperialism: The Biological Expansion of Europe, 90o-190o (Cambridge: Cambridge University Press, 1986); William H. NcNeill, Plagues and Peoples (Garden City, New York: Anchor Press/Doubleday, 1976); Kenneth F. Kiple, The Caribbean Slave: A Biological History (Cambridge: Cambridge University Press, 1984); Kiple, The African Exchange: Toward a Biological History of Black People (Durham: Duke University Press, I988). 
cal and ecological history of disease are usually based on material (mostly, human, animal, vegetable, and microbial remains) as well as documentary (written and iconographical) sources. In these constructions present-day medical and scientific knowledge is the representational framework from which the different sources are interpreted. Moreover, in the case of the material sources, it also provides the technico-experimental pillar of such interpretation. All this unavoidably introduces into these historical constructions a certain degree of anachronism which varies according to their level of sophistication and the historical period studied.

On the other hand, these constructions deal with an unavoidable restriction: the impossibility of experimentally reproducing the biological and ecological conditions that accompanied the appearance and recognition of any past disease. Only this experience - unimaginable for technical and, above all, ethical reasons - could provide the definitive evidence to validate or refute these historical constructions. In the face of such limitations, present-day paleopathology and historical demography and epidemiology have developed by combining fragmentary evidence from a wide range of research sources and methods inside and outside their traditional disciplinary boundaries. This has meant, on the one hand, more sophisticated statistical analysis of human populations and their diseases; on the other, a gradual interdisciplinary approach including knowledge and techniques from contemporary medicine and science, history of medicine, bio-anthropology, social anthropology, sociology, and others. ${ }^{50}$

In an interdisciplinary workshop on diagnostic expressions as causes of death, held in Valencia, Spain in $1993,{ }^{51}$ chafing at the objections medical historians posed to making epidemiological sense of past diagnostic expressions, a historical demographer joked that he was not concerned about that rather theoretical discussion; he just wanted to know in which box of the International Classification of Diseases he

50. The demographic and epidemiological studies of present-day and developing societies have proved since Ackerknecht to be one of the most useful auxiliary tools for this purpose because they offer a geographical approach to the history of human. See Erwin H. Ackerknecht, Geschichte und Geographie der wichtigsten Krankenheiten (Stuttgart: F. Enke, 1963) [History and Geography of the Most Important Diseases (New York/London: Hafner, 1966)]; Ann G. Carmichael, Plague and the Poor in Renaissance Florence (Cambridge: Cambridge University Press, 1986).

SI. Expresiones diagnósticas y causas de muerte. Workshop organized by Josep BernabeuMestre and Elena Robles, Valencia, June 1993. The results of this workshop were published as monograph of Bol. Asoc. Demografia Histórica, 1993, 11, no. 3. 
260 Jourmal of the History of Medicine : Vol. 54, April 1999

was supposed to put each single cause of death he was recording from the archival sources. I do not hesitate to claim that this issue can be legitimately approached and to some extent given a reliable answer. But in the demographer's comment there lurks a transcultural historical interpretation that is not so easy to render as might appear at first sight. In this paper I have tried to show some of its complexities from an historico-medical viewpoint. 